\title{
CRATICULA BUDERI (BACILLARIOPHYCEAE) IN POLAND
}

\author{
SylWia Cichoń
}

Sylwia Cichoń, AGH University of Science and Technology, Al. Mickiewicza 30,30-059 Kraków, Poland; e-mail: scichon@agh.edu.pl

Craticula buderi (Hustedt) Lange-Bertalot was established by Hustedt in 1954 as Navicula buderi, after which this diatom was transferred to the genus Craticula by Lange-Bertalot (Rumrich et al. 2000). I found several specimens of $C$. buderi in the Chechło River in southern Poland during diatomological studies of this area. Craticula buderi is known from North America (USA; e.g., Bahls 2009), South America (Colombia; e.g., MontoyaMoreno et al. 2013), Australia (Queensland) and New Zealand (Bostock \& Holland 2010), and the Middle East (Israel; Tsarenko et al. 2000). In the Arctic it is known from Ellesmere Island (Michelutti et al. 2013), and in Europe from Great Britain (Hartley et al. 1986), Germany (Hofmann et al. 2013) and Romania (Cărăuş 2012). This diatom is widespread in Central Europe, where it is known from water of high calcium content and moderate to higher electric conductivity, including saline water (Lange-Bertalot 2001; Bąk et al. 2012; Pliński \& Witkowski 2013). Previously the species was reported only from two localities in northern and central Poland (Dziengo 2003; Żelazna-Wieczorek 2011; Fig. 1). There is little published data on the distribution of $C$. buderi in Poland. For the diatom names regarded as synonyms of Craticula buderi (Navicula pseudohalophila Cholnoky 1960, Navicula adsidua R. E. M. Archibald 1971) I found no information on their distribution in Poland. Other Navicula species similar to Craticula buderi [Navicula simplex Krasske, $N$. halophila (Grunow) Cleve] are known from Poland (Siemińska \& Wołowski 2003). Navicula simplex Krasske is known from the Baltic coastal zone (Rumek 1948; Mańkowski \& Rumek 1975; Ringer
1985), the Mazurian area (Chudyba 1979), the Vistula River near Warsaw (Wysocka 1952; Tyszka-Mackiewicz 1983) and a fish pond in Mydlniki near Kraków (Siemińska 1947). The last diatom that can be mistaken for Craticula buderi is $\mathrm{Na}$ vicula halophila $[=$ Craticula halophila (Grunow ex Van Heurck) Mann]. Craticula buderi was regarded as a synonym of Navicula halophila by Krammer and Lange-Bertalot (1986). Now these two species are treated as separate taxa, Craticula buderi and C. halophila, which differ considerably in valve shape and size (Lange-Bertalot 2001). Craticula halophila is well known from saline springs and waters of high to very high electrolyte content.

This publication discusses the distribution of Craticula buderi in Poland and provides brief information about its morphological variability in LM and SEM, observed in the samples collected from the Chechło River.

Craticula buderi (Hustedt) Lange-Bertalot

Figs 1-14

in Rumrich, Lange-Bertalot \& Rumrich 2000; Navicula buderi Hustedt 1954; Navicula pseudohalophila Cholnoky 1960; Navicula adsidua R. E. M. Archibald 1971.

The observed valves $(n=27)$ are 15.2-27.7 $(21.29 \pm 3.15) \mu \mathrm{m}$ long and 4.9-6.6 (5.93 $\pm 0.47) \mu \mathrm{m}$ wide, and are ornamented with 16-22 $(19.58 \pm 1.49)$ striae in $10 \mu \mathrm{m}$. They are lanceolate with short protracted rostrate apices (Figs 2-9, 12). The axial area is linear and very narrow (Figs 2-9, 12). The central area is only slightly wider than the axial area and elliptic in shape (Figs 9, 10, 12, 13). 


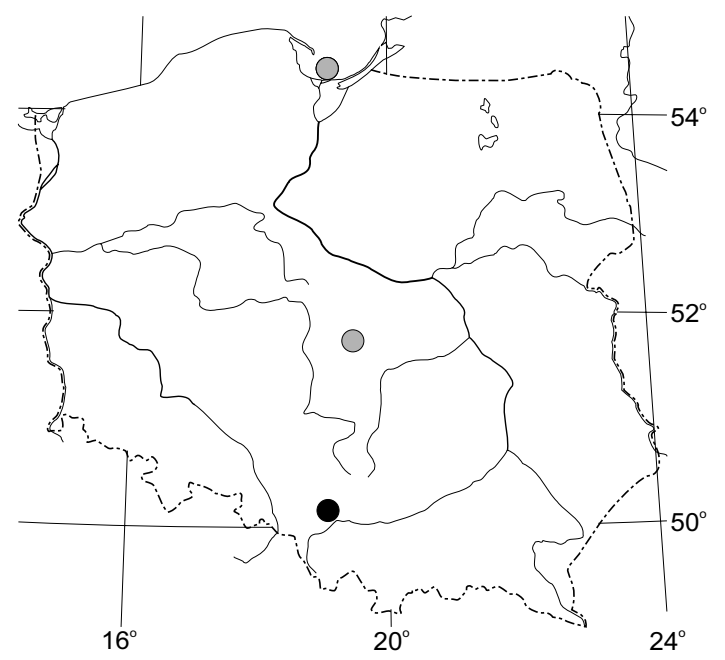

Fig. 1. Distribution of Craticula buderi (Hustedt) Lange-Bertalot in Poland. Grey dots show the known localities given by Dziengo (2003) and Żelazna-Wieczorek (2011). Black dot shows a new locality in the Chechło River given here.

The raphe is filiform with near-straight proximal ends (Figs 10,13) and distal ends hooked in the same direction (Figs 9, 11). The striae are parallel (Figs 13, 14) to very weakly radiate at the valve center (Figs 10,13), becoming convergent towards the apices (Figs 11, 14). The areolae are of very fine structure, making them difficult to resolve in LM; they are apically elongated, lying in single rows, 46-55 in $10 \mu \mathrm{m}$.

Craticula buderi was first mentioned by Dziengo (2003) from northern Poland in the Gulf of Gdańsk, Baltic Sea. The second locality was given by Żelazna-Wieczorek, who noted it in three springs in Łódź, central Poland (2011). The occurrence of this diatom in the Chechło River in southern Poland confirms the tolerance range of C. buderi, which is known from habitats polluted by industrial waste. The sample with $C$. buderi was collected in 2015 from sandy bottom in the Chechło River, where $\mathrm{pH}$ was 7.5 and ionic composition was as follows: phosphate $\left(\mathrm{PO}_{4}{ }^{3+}\right)$ $0.3 \mathrm{mg} \mathrm{l}^{-1}$, nitrate $\left(\mathrm{NO}_{3}^{-}\right) 0.4 \mathrm{mg} \mathrm{l}^{-1}$, chlorine $\left(\mathrm{Cl}^{-}\right)$ $58.2 \mathrm{mg} \mathrm{l}^{-1}$, calcium $\left(\mathrm{Ca}^{2+}\right) 72.2 \mathrm{mg} \mathrm{l}^{-1}$, and sulphate $\left(\mathrm{SO}_{4}{ }^{2-}\right) 105.8 \mathrm{mg} \mathrm{l}^{-1}$. The water was rich in heavy metals such as cadmium $\left(\mathrm{Cd} 2.5 \mu \mathrm{g}^{-1}\right)$ copper $\left(\mathrm{Cu} 5.0 \mu \mathrm{g} \mathrm{l}^{-1}\right)$ and zinc $\left(\mathrm{Zn} 90.0 \mu \mathrm{g} \mathrm{l}^{-1}\right)$.
The drainage basin of the Chechło River is built partly of tectonically dislocated Triassic dolomite which contains zinc and lead ore, and the river also is polluted by municipal sewage from the town of Chrzanów. The Chechło has a catchment area of $c a 110 \mathrm{~km}^{2}$ and drains the southern part of the Silesian-Cracow Upland. It is $23 \mathrm{~km}$ long and the mean annual flow in the lower course of the river is $1.5 \mathrm{~m}^{3} \mathrm{~s}^{-1}$. The eastern part of the drainage basin is Jurassic limestone and Permian conglomerates; the remaining part is composed of the mentioned tectonically dislocated Triassic dolomite. The dolomite contains rich deposits of zinc and lead ore; mining began there as far back as the Middle Ages. The landscape is dominated by horst hills 300-400 m a.s.l. high, separated by depressions (ca 200-300 m a.s.l.) filled with fluvioglacial sand. The hill slopes are steep and rise 50-100 $\mathrm{m}$ above the local ground level (Ciszewski 1997).

The most abundant diatom taxa dominating in the diatom assemblages with $C$. buderi include Nitzschia capitellata Hustedt, Planothidium frequentissimum (Lange-Bertalot) Lange-Bertalot, Navicula gregaria Donkin, Hippodonta capitata (Ehrenberg) Lange-Bertalot, Metzeltin \& Witkowski, P. lanceolatum (Brebisson ex Kützing) Lange-Bertalot, Gomphonema micropus Kützing, Achnanthidium minutissimum (Kützing) Czarnecki, Cocconeis placentula var. placentula (Ehrenberg) Grunow, Eolimna minima (Grunow) Lange-Bertalot, N. palea var. debilis (Kützing) Grunow, G. parvulum (Kützing) Kützing, Mayamaea atomus var. permitis (Hustedt) Lange-Bertalot, Lemnicola hungarica (Grunow) Round \& Basson. Bioindicative diatom taxa are: Parlibellus protractoides (Hustedt) Witkowski \& Lange-Bertalot, Mayamaea atomus var. permitis (Hustedt) Lange-Bertalot, Nitzschia amphibia Grunow, N. palea, Planothidium frequentissimum, Sellaphora pupula, Surirella brebissonii var. kuetzingii Krammer \& Lange-Bertalot, Achnanthidium minutissimum, Aulacoseira granulata (Ehrenberg) Simonsen, Cyclotella meneghiniana Kützing, $C y$ matopleura solea (Brébisson) W. Smith, Gomphonema parvulum, Hippodonta capitata, Melosira varians C. Agardh, Navicula cryptocephala Kützing, $N$. gregaria Donkin, $N$. lanceolata Ehrenberg 

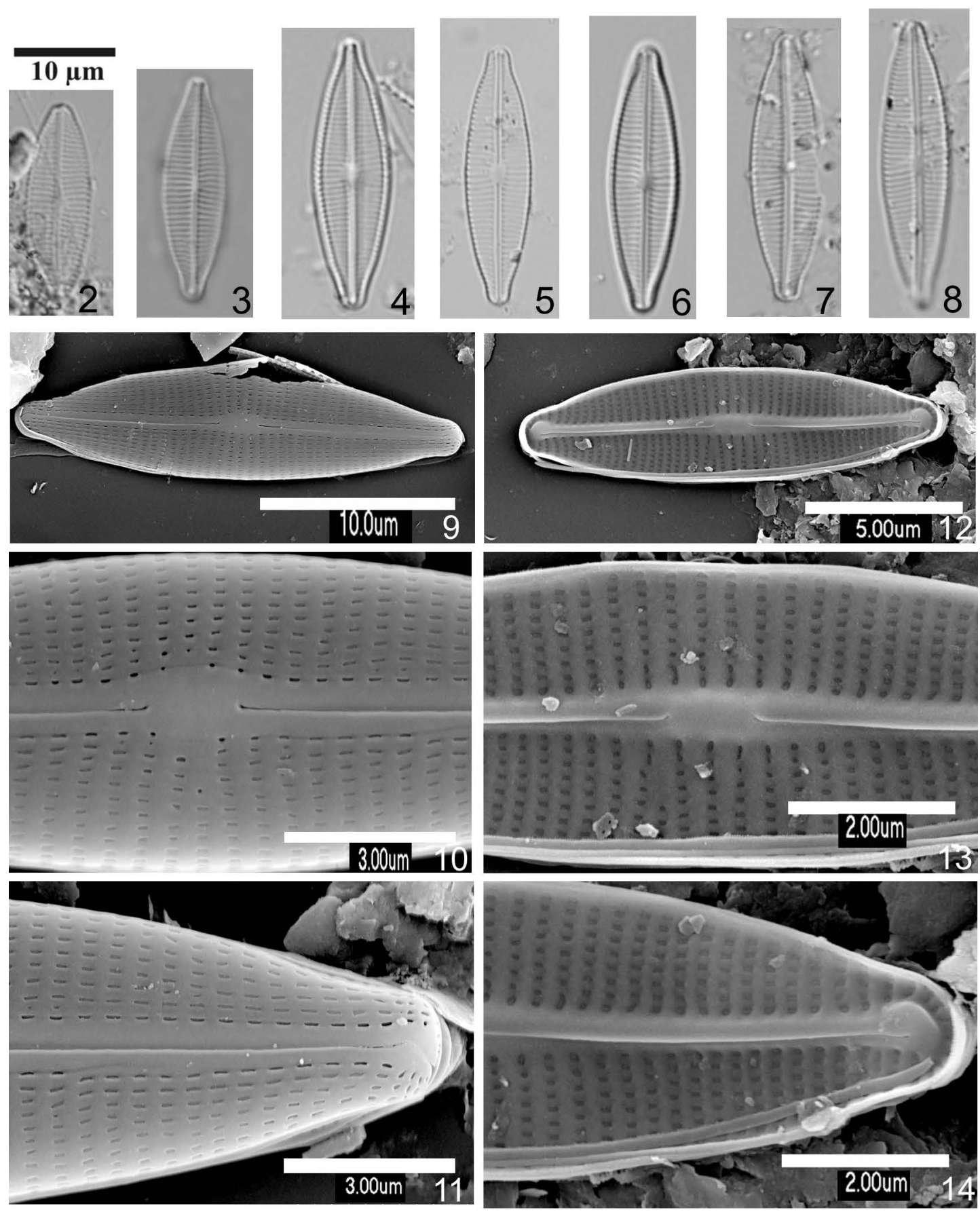

Figs 2-14. Craticula buderi (Hustedt) Lange-Bertalot in LM (2-8) and SEM (9-14). 2-9 \& 12 - variation of outline and size of the recorded valves, which are lanceolate with short protracted rostrate apices; $9 \& 12$ - linear, very narrow axial area; 9 , 10, $12 \& 13$ - central area slightly wider than axial area, and elliptic in shape; $10 \& 13$ - filiform raphe with near-straight proximal ends; $9 \& 11$ - distal ends hooked in the same direction. 9-11 - exterior view of valve; $12-14$ - interior view of valve. 
and Nitzschia linearis W. Smith. They are diatoms common in eutrophic waters, showing a wide range of tolerance of pollution (Bąk et al. 2012). The observed valves of Craticula buderi found in the Chechło River fall within the known range of morphological variability of this diatom. They are 15.2-27.7 $\mu \mathrm{m}$ long, 4.9-6.6 $\mu \mathrm{m}$ wide and have 16-22 striae in $10 \mu \mathrm{m}$; according to Bąk et al. (2012) the range of dimensions of $C$. buderi is wider (10-40 $\mu \mathrm{m}$ long, 5-8 $\mu \mathrm{m}$ wide, $17-21$ striae in $10 \mu \mathrm{m})$. Slightly narrower valves as well as those having 16 or 22 transapical striae in $10 \mu \mathrm{m}$ were individual cases.

Acknowledgements. I am indebted to Professors Agata Z. Wojtal and Dariusz Ciszewski for their help during the work, valuable suggestions and advice, critical comments on taxonomical problems, and critically reading the manuscript. I thank the anonymous reviewer for constructive suggestions. The research was supported by grant no. 2014/15/B/ST10/03862 from the Polish National Science Centre.

\section{REFERENCES}

ArChibald R. E. M. 1971. Diatoms from the Vaal Dam Catchment Area, Transvaal, South Africa. Bot. Mar. 14(Suppl. 1): $17-70$.

BAHLS L. L. 2009. A checklist of diatoms from inland waters of the Northwestern United States. Proc. Acad. Nat. Sci. Philadelphia 158(1): 1-35.

Bąk M., Witkowski A., ŻElazna-Wieczorek J., Wojtal A. Z., Szczepocka E., Szulc A. \& Szulc B. 2012. Klucz do oznaczania okrzemek $w$ fitobentosie na potrzeby oceny stanu ekologicznego wód powierzchniowych w Polsce. Biblioteka Monitoringu Środowiska, Warszawa.

Bostock P. D. \& Holland A. E. (eds) 2010. Census of the Queensland Flora. Department of Environment and Resource Management, Queensland Herbarium, Brisbane.

CĂRĂUŞ I. 2012. Algae of Romania. A distributional checklist of actual algae. Version 2.3 third revision. University of Bacau, Bacau.

Cholnoky B. J. 1960. Beiträge zur Kenntnis der Diatomeenflora von Natal (Südafrica). Nova Hedwigia 2(1/2): 1-128.

Chudyba H. 1979. Special composition and number of the phytoplankton of the lakes of the Mazurian Landscape Park. Acta Hydrobiol. 21(2): 105-116.

CiszewsKi D. 1997. Source of pollution as a factor controlling distribution of heavy metals in bottom sediments of
Chechło River (south Poland). Environmental Geology 29(1/2): 50-57.

DzIEngo M. 2003. Diatoms (Bacillariophyceae) - Ecological values. Instytut Oceanografii, Uniwersytet Gdański, Gdańsk.

Hartley B., Ross R. \& Williams D. M. 1986. A check-list of the freshwater, brackish and marine diatoms of the British Isles and adjoining coastal waters. J. Mar. Biol. Assoc. U.K. 66(3): 531-610.

Hofmann G., Werum M. \& Lange-Bertalot H. 2013. Diatomeen im Süßwasser-Benthos von Mitteleuropa. Koeltz Scientific Books, Königstein.

Hustedt F. 1954. Neue und wenig bekannte Diatomeen. VI. Ber. Deutsch. Bot. Ges. 67: 269-280.

Krammer K. \& Lange-Bertalot H. 1986. Bacillariophyceae. 1. Naviculaceae. In: H. Ettr, J. Gerloff, H. Heynig \& D. Mollenhauer (eds), Sußwasserflora von Mitteleuropa. 2(1): 1-876 \& 206 Pls. G. Fisher Verlag, Jena.

Lange-Bertalot H. 2001. Navicula sensu stricto. 10 Genera separated from Navicula sensu lato. Frustulia. Diatoms of Europe: diatoms of the European inland waters and comparable habitats. 2: 1-526. A.R.G. Gantner Verlag K.G., Ruggell.

MaŃkOwski W. \& RumeK A. 1975. The succesion of foulting of submerged objects by flora and fauna in annual cycle. Biologia Morza 2: 15-44.

Michelutti N., McCleary K., Douglas M. S. V. \& Smol J. P. 2013. Comparison of freshwater diatom assemblages from a high Arctic oasis to nearby polar desert sites and their application to environmental inference models. J. Phycol. 49(1): 41-53.

Montoya-Moreno Y., Sala S., Vouilloud A., Aguirre N. \& Plata Y. 2013. Lista de las diatomeas de ambientes continentales de Colombia. Biota Colombiana 14(2): 13-78.

PliŃski M. \& Witkowski A. 2013. Okrzemki-Bacillariopyta (Diatoms) (with the English key for the identification to the genus). Część trzecia: Okrzemki pierzaste (Lyrellales, Mastogloiales, Cymbellales, Naviculales). Part three: Pennate diatoms II. In: M. PLIŃsKi (ed.), Flora Zatoki Gdańskiej $i$ wód przyleglych (Baltyk Poludniowy). 4(3): 1-246. Wydawnictwo Uniwersytetu Gdańskiego, Gdańsk.

RINGER Z. 1985. Roślinność Zatoki Gdańskiej. In: Badania sozologiczne i ekologiczne zwierząt morskich. Studia i Materialy, Morski Instytut Rybacki 26: 43-69.

RUMEK A. 1948. List of the phytoplankton species occuring in the superficial water layers in the Gulf of Gdańsk. Biuletyn Morskiego Laboratorium Rybackiego w Gdyni 4: 139-141 (in Polish).

Rumrich U., Lange-Bertalot H. \& Rumrich M. 2000. Diatomeen der Anden von Venezuela bis Patagonien/Feuerland und zwei weitere Beiträge. Diatoms of the Andes. From Venezuela to Patagonia/Tierra del Fuego and two additional contributions. Iconogr. Diatomol. 9: 1-673. 
SIEMIŃSKA J. 1947. The winter flora of diatoms in the ponds of the Fishery Experimental Station of the Jagiellonian University at Mydlniki by Cracow. Arch. Hydrobiol. Rybactwa 13: 181-220 (in Polish with English summary).

Siemińska J. \& Wolowski K. 2003. Catalogue of Polish prokaryotic and eukariotic algae. Biodiversity of Poland 5. W. Szafer Institute of Botany, Polish Academy of Sciences, Kraków.

Tsarenko P. M., Lange-Bertalot H., Stupina V. V. \& Wasser S. P. 2000. Bacillariophyta. In: E. Nevo \& S. P. WASSER (eds), Biodiversity of Cyanoprocaryotes, Algae and Fungi of Israel. Cyanoprocaryotes and algae of continental Israel, pp. 195-335. A.R.A. Gantner Verlag K.-G., Ruggell.
TYSZKA-MACKIEWICZ J. 1983. Bioseston and periphyton of Vistula river in its section from Puławy to Warsaw. Prace Komis. Biol. 63: 3-114 (in Polish with English summary).

Wysocka H. 1952. Algues de la Vistule au rayon de Varsovie. Partie II: Periphyton. Acta Soc. Bot. Poloniae 21(3): 369-400.

Żelazna-Wieczorek J. 2011. Diatom flora in springs of Lódź Hills (Central Poland). Biodiversity, taxonomy and temporal changes of epipsammic diatom assemblages in springs affected by human impact. A.R.G. Gantner Verlag K.G., Ruggell. 